ANNA H. FIDELUS
Wydział Nauk Pedagogicznych
Uniwersytet Kardynała Stefana Wyszyńskiego w Warszawie
Forum Pedagogiczne

2017/1

Wpłynęło: 15.02.2017

Zatwierdzono do druku: 29.03.2017

DOI: $10.21697 / \mathrm{fp} .2017 .1 .04$

\title{
PRACA ZE SKAZANYMI Z PERSPEKTYWY MODELU SPOLECZNO-PRZESTRZENNEGO
}

\begin{abstract}
Streszczenie: Resocjalizacja osób mających za sobą doświadczenie kary pozbawienia wolności to kwestia od lat pozostająca w centrum zainteresowania zarówno naukowców, praktyków, jak i znaczącej części społeczeństwa. We współczesnej teoretycznej refleksji i metodycznych kontekstach pracy resocjalizacyjnej dominuje podejście indeterministyczne, pozostające głównie w nurcie kognitywnej i interakcjonistycznej wizji człowieka i społeczeństwa. Szczególnie wywodzące się z tej przestrzeni socjologia, pedagogika kultury, psychologia i pedagogika twórczości, psychologia poznawcza, pedagogika personalistyczna, heurystyka, podejście fenomenologiczne - inspirują współczesną działalność resocjalizacyjną. W niniejszym artykule podjęto próbę wykorzystania modelu społeczno-przestrzennego w procesie resocjalizacji inkluzyjnej. Praktyczne uwagi wynikające z zaprezentowanych refleksji zostały zinterpretowane w odniesieniu do osób mających za sobą pobyt w izolacji więziennej. Wynika to z doświadczeń autorki tekstu prowadzącej badania w grupie osób skazanych. Niewątpliwie jednak analizowane w opracowaniu kwestie w całej rozciągłości mogą być wykorzystywane w praktyce resocjalizacji inkluzyjnej, w odniesieniu do wszystkich osób wymagających pomocy i wsparcia w określonej przestrzeni społecznej.
\end{abstract}

Słowa kluczowe: resocjalizacja inkluzyjna, model społeczno-przestrzenny, relacyjność.

\section{Wprowadzenie}

Readaptacja społeczna osób mających za sobą doświadczenie kary pozbawienia wolności to kwestia od lat pozostająca w centrum zainteresowania zarówno naukowców, praktyków, jak i znaczącej części społeczeństwa. Praca z byłymi więźniami w warunkach wolnościowych jest naturalną kontynuacją i wzmocnieniem zainicjowanego w zakładzie karnym procesu resocjalizacji. Teoretycznie się zakłada, że proces resocjalizacji w zakładzie karnym powinien być na tyle efektywny, aby osoba opuszczająca tę instytucję pozbawiona była jakichkolwiek problemów i w środowisku wolnościowym funkcjonowała zgodnie z normami społecznymi, moralnymi i prawnymi. Niestety, nie zawsze tak jest. W praktyce się dostrzega, że osoby, które opuszczają więzienie, odczuwają ewidentne trudności z przystosowaniem się do 
życia w warunkach wolnościowych. Te problemy wynikają zarówno z braku skutecznych działań podejmowanych w zakładzie karnym, jak również mają swoje źródło w uwarunkowaniach towarzyszących pobytowi w instytucji o charakterze totalnym. Zauważa się, że typowe dla skazanych jest wypracowanie odpowiednich mechanizmów adaptacyjnych, ułatwiających życie w instytucji totalnej (Goffman 2011). Niestety, gdy skazani powracają do życia na wolności, ciągle posługują się wypracowanymi w izolacji technikami, co obok innych zmiennych występujących w środowisku lokalnym zdecydowanie utrudnia przebieg relacji społecznych w warunkach wolnościowych. Z tego też względu mocno się podkreśla, że przygotowanie skazanego do uczestnictwa w życiu społecznym, w zgodzie z obowiązującymi zasadami i normami, powinno rozpocząć się co najmniej w momencie uruchomienia wobec niego postępowania resocjalizacyjnego, a nawet już w chwili zatrzymania danej osoby przez organy ścigania. Aby proces readaptacji społecznej skazanych przebiegał pozytywnie po opuszczeniu przez nich więzienia, należy już w pierwszym okresie pobytu w więzieniu mieć na uwadze takie działania, które sprzyjałyby inkluzji społecznej. Należy pamiętać, że im bardziej proces resocjalizacji będzie przebiegał w „oderwaniu od społeczeństwa i podstawowych środowisk społecznego uczestnictwa jednostki, tym bardziej będzie pozostawał w sprzeczności z istotą samego procesu uspołecznienia, w tym i ponownego przystosowania eksdewianta do życia na wolności” (Goffman 2011, s.185). W niniejszym artykule zwrócono uwagę na uwarunkowania procesu włączania byłych więźniów w nurt życia na wolności z perspektywy modelu społeczno-przestrzennego. Szczególnie zaakcentowano specyfikę relacji zachodzących w określonym środowisku życia, które nie pozostają bez wpływu na uwarunkowania procesu resocjalizacji inkluzyjnej.

\section{Określenie „przestrzeń społeczna”}

Określenie „przestrzeń społeczna” jest złożone i niejednorodne. Sama dwoistość nazwy wyznacza znaczną przestrzeń interpretacyjną kryjącą się pod tym pojęciem. W literaturze przedmiotu spotykamy liczne koncepcje poświęcone zarówno „przestrzeni”, jak i „społeczności”. Paradygmat przestrzeni społecznej, ukrytej pod pojęciem Sozialraum, szczególnie popularyzowany jest w literaturze niemieckiej z obszaru pedagogiki społecznej i pracy socjalnej. Jednak nie należy zapominać o rodzimej literaturze i dorobku polskich pedagogów społecznych, którzy równie silnie podkreślali istotę i siłę kryjącą się w przestrzeni społecznej, używając także innych, pokrewnych określeń. Wielu znanych pedagogów społecznych (Radlińska, Kowalski, Kamiński, Marynowicz-Hetka, Theiss, Smolińska-Theiss, Pilch, Winiarski) w swoich rozprawach używało i aktualnie wykorzystuje określenie „środowisko życia”, podkreślając jego rolę przyczyniającą się do rozwoju każdego człowieka. Przypominając chociażby określenie Heleny Radlińskiej, zgodnie z którym środowisko życia określone jest jako „zespół warunków przyrodniczych, kulturowych, osobowo-społecznych, wśród których żyje jednostka, i czynników 
przekształcających jej osobowość, zakładając dialektyczną współzależność między środowiskiem wychowującym a jednostkami lub grupami wychowywanymi" (Kowalski 1993, s. 72-73), dostrzegamy elementy, które pojawiają się w aktualnych opisach przestrzeni społecznej. Przywołując natomiast charakterystykę przestrzeni społecznej za Andreasem Hopmannem, zauważamy szerokie ujęcie tego pojęcia, uwzględniające wiele różnorodnych cech. Hopmann odnotował, że przestrzeń społeczna może być interpretowana jako:

- terytorium (administracja);

- ramy planowania (planowanie społeczno-socjalne);

- czynnik sterowania (polityka);

- ramy interwencji (pedagogika społeczna i praca socjalna);

- obszar oddziaływania itp. (dzielnica, instytucja);

- środowisko życiowe (mieszkańców);

- zasoby (potencjał i źródła przezwyciężania trudności) (Hopmann 2006).

Biorąc pod uwagę rozumienie przestrzeni społecznej przez Hopmanna, utwierdzamy się w przekonaniu o trudności doprecyzowania samej nazwy. Można stwierdzić, że określenie „przestrzeń społeczna” charakteryzuje się wzajemną komplementarnością wynikającą z odmiennych odniesień teoretyczno-praktycznych. Podstawowym spoiwem tego określenia jest jego normatywność, wyrażająca się nie tyle w geograficznie i politycznie określonym zakresie, jakby w sensie okręgu wyborczego, ile w perspektywie etnograficznej, jako obszar czy też dzielnica, które z wewnętrznej perspektywy mieszkańców wykazują osobliwe cechy wspólne, mogące prowadzić w określonych warunkach do sytuacyjnej definicji „MY” (Surzykiewicz 2010, s. 203).

\section{Relacyjne rozumienie przestrzeni społecznej z perspektywy kreowania środowiska inkluzyjnego}

Z perspektywy podjętego tematu - społeczno-przestrzennego modelu pracy z osobami mającymi za sobą pobyt w zakładzie karnym - za najbardziej zasadne postuluję przyjąć relacyjne rozumienie przestrzeni społecznej, rozumianej jako forma wytworu ludzkiego działania w konkretnym kontekście społecznym, który z czasem nabiera autonomicznego charakteru i może zdominować relacje międzyludzkie zachodzące na jego obszarze (Berger, Luckmann 1980). W pełni utożsamiam się ze stanowiskiem Silvii Staub-Bernasconi, która zauważyła, że ujęcie przestrzeni społecznej właśnie z perspektywy relacyjnej pozwoli na uniknięcie podstawowego zagrożenia wynikającego $\mathrm{z}$ faktu przewartościowania $\mathrm{z}$ jednej strony absolutnie subiektywnej percepcji rzeczywistości przez jednostkę - poprzez zwrócenie uwagi na znaczenie struktur społecznych - a z drugiej strony - ze względu na krytyczne ustosunkowanie się do podejścia paternalistycznego, lansującego społeczeństwo bez podmiotów jednostkowych - zabezpieczy wymowę indywidualnej perspektywy w postrzeganiu przestrzeni społecznej (Staub-Bernasconi 2007, s. 160). Efekty 
resocjalizacyjne w odniesieniu do osób mających za sobą przeszłość więzienną uzależnione są przecież zarówno od aktualnych rozwiązań systemowych i podejmowanych w ich następstwie różnorodnych działań zarówno w zakładzie karnym, jak i od konkretnych sytuacji przebiegających w środowisku otwartym. Znaczącą rolę w życiu osób z doświadczeniem więziennym odgrywa specyfika środowiska lokalnego, ze szczególnym, osobliwym charakterem „przestrzeni międzyludzkiej”, w której skazany funkcjonuje po opuszczeniu więzienia. Należy przy tym zauważyć, że owej „przestrzeni nie powinno się traktować ani jako absolutnej rzeczywistości, ani też jako zupełnie subiektywnej, względnej jej percepcji" (Kessl, Reutlinger 2007, s. 27). Przestrzeń społeczna wyraża się w dynamicznej tkance społecznej i materialnych działaniach, które podlegają stałej (re)produkcji na różnych poziomach (inter)akcji i relacji. Podążając tym tokiem myślenia, przestrzenie społeczne należy uznać za podwójne struktury z połączonymi dwoma perspektywami (Deinet 2007, s. 113-120). Obraz przestrzeni społecznej jest finalnym wytworem wzajemnie przenikających się zachowań jednostkowych w konkretnej konstelacji społecznych struktur. W żadnej mierze nie można określić dominującego wpływu jednej bądź drugiej strony - jednostki lub środowiska. Przestrzeń społeczną rozumie się ogólnie jako układ relacyjny, zachodzący np. wśród zwierząt (w rozumieniu zoologicznym) czy też na poziomie pogrupowanych dóbr socjalnych (ujęcie socjalne), a także w społecznym sensie - jako ludzi zamieszkujących i pozostających w relacjach na wspólnym terenie (Löw i in. 2008, s. 63). Każdy człowiek posiada unikalną tylko dla siebie, niepowtarzalną sieć relacji z różnorod nymi osobami w określonej przestrzeni społecznej. Te relacje, zachodzące pomiędzy przypadkowymi i różnorodnymi osobami i położeniami prowadzą do wytworzenia się odpowiedniej przestrzeni. Każdy człowiek funkcjonuje więc w określonej przestrzeni społecznej, czy używając metafory użytej z perspektywy trzeciej socjologii - przestrzeni międzyludzkiej.

Dostrzegamy więc, że samo rozumienie przestrzeni społecznej uzależnione jest od przyjętego punktu widzenia, od tradycji myślowych, „różni się ono znacznie tym, na ile uwzględnia kryterium relacji i interakcji zachodzących pomiędzy rozumieniem przestrzenności (miejscem fizycznym, obszarem otoczeniem, środowiskiem, geografią, planem miasta) a ich odniesieniem do podmiotów społecznych (jednostki, grupy społeczne czy też całe społeczeństwa), a konkretniej, ich percepcji poznawczo-emocjonalnej i behawioralnej kategorii przestrzeni" (Löw i in. 2008, s. 33-34). Należy także podkreślić, że przestrzenie społeczne nie pozostają stałe raz na zawsze, ale ulegają nieustannej modyfikacji, nie można też z góry założyć i zrealizować określonej konstrukcji przestrzeni społecznej. Co więcej, określone przestrzenie społeczne mogą nawet zaniknąć, jeżeli ich twórcy zrezygnują z przebywania w nich. Jakość ich istnienia uzależniona jest od ich członków, realizatorów. $Z$ tego względu przestrzenie społeczne uważane są za społeczności o krótkim zasięgu, o tymczasowych charakterze, które istnieją głównie na poziomie lokalnym bądź regionalnym (Kessl, Reutlinger 2007, s. 23). Powyższa uwaga dotycząca zmienności przestrzeni społecznej jest bardzo istotna z perspektywy sytuacji 
osób mających za sobą pobyt w więzieniu. Zachowania mieszkańców świadczące o ich określonych postawach wobec osób $\mathrm{z}$ doświadczeniem więziennym, które są niewątpliwie znaczącym elementem określonych przestrzeni społecznych, mogą ulec przeobrażeniu. Tak więc przestrzenie społeczne niesprzyjające lub wspierające proces inkluzji ulegają zmianie. Należy więc uważnie obserwować relacje mieszkańców w określonych środowiskach lokalnych. Wskazane jest również, aby mieć na uwadze fakt, że ustalone rozwiązania w przestrzeni społecznej powinny być modyfikowane, głównie ze względu na ich ewentualne przeobrażenia. $\mathrm{Na}$ efektywność pracy resocjalizacyjnej znaczący wpływ mają owe wzajemne relacje występujące w określonej przestrzeni społecznej. Przy zmianie charakteru relacji społecznej pojawia się nowy obraz tej przestrzeni, który generuje kolejne zmiany w funkcjonowaniu zarówno jednostek, rodziny, jak i struktur społecznych.

Analiza określonej przestrzeni społecznej, z uwagi na konieczność podjęcia rozwiązań sprzyjających resocjalizacji o charakterze inkluzyjnym, powinna mieć charakter praktycznego podejścia badawczego. W tym celu osoby koordynujące rozwiązywanie problemów społecznych w danej przestrzeni, np. na poziomie wsi, dzielnicy, miasta, gminy, powinny skoncentrować się na skonkretyzowaniu problemów - „konkretne problemy rozumie się jako wynikające ze społecznych powiązań, pozycji i ról odgrywanych przez jednostkę systemie społecznym" (Hinte, Treess 2007). Pomocne przy tym mogą okazać się np. badania sondażowe, pozwalające na rozpoznanie postaw społeczeństwa wobec skazanych i odwrotnie - poznanie stosunku skazanych, ich rodzin do mieszkańców danej przestrzeni. Przyjmuje się, że metodyczne działanie nie przebiega w neutralnej przestrzeni - analiza przestrzeni społecznej powinna być tak zaprojektowana, aby pozwoliła na ujawnienie specyfiki interaktywności i relacyjności zachodzących pomiędzy jednostką (byłym więźniem), rodziną a strukturą społeczną. Dlatego też bardzo ważne jest odnalezienie wszystkich zasobów pozwalających na rozwój i wsparcie środowiska społecznego w kierunku rozwoju jego charakteru inkluzyjnego. Poszukiwaniu czynników wspierających powinny również towarzyszyć działania diagnozujące słabe strony określonej przestrzeni społecznej. Poznanie tych czynników pozwoli głównie na ich wyeliminowanie, ułatwiając jednocześnie projektowanie takich rozwiązań inkluzyjnych, które pozbawione będą elementów sprzyjających pojawianiu się ewentualnych zagrożeń w przebiegu procesu inkluzyjnego. Należy również zwrócić uwagę na dokładne zaplanowanie podstawowych działań sprzyjających inkluzji, tak na poziomie indywidualnym - w odniesieniu do konkretnego skazanego i jego rodziny, jak również na poziomie strukturalnym, uwzględniając możliwie wszystkie grupy i instytucje należące do danej przestrzeni społecznej (zasoby społeczne). Główny fokus badawczy przy dokonywaniu analizy przestrzeni społecznej wymaga pełnej koncentracji na dialektyce zachodzącej pomiędzy przestrzenią a rozwojem (społecznym) (Reutlinger 2009, s. 19). Analizując przestrzeń społeczną z perspektywy działań pomocowych dla skazanych i ich rodzin, należy przede wszystkim poznać możliwości rozwojowe i ich potencjał. W prowadzonej 
analizie punktem wyjścia powinno być założenie, że to sami skazani i ich najbliżsi przebywający w danej przestrzeni są ekspertami w dziedzinie własnego życia, własnych możliwości rozwojowych, oczekiwań i tworzenia warunków sprzyjających rozwiązywaniu osobliwych problemów. Z tego też względu to byłym więźniom i ich najbliższym żyjącym w określonej przestrzeni społecznej należy się uznanie dla ich niepowtarzalnej godności i wyrażenie szczególnej uwagi i zainteresowania.

Podejmując analizę zagadnień związanych z przestrzenią społeczną z perspektywy uwarunkowań procesu inkluzji, koniecznym warunkiem jest bardzo dobra orientacja w specyfice i uwarunkowaniach jej funkcjonowania. Należy odpowiedzieć na pytanie, czy jedna osoba jest w stanie właściwie, z perspektywy różnych obszarów, zdiagnozować daną przestrzeń społeczną? Z pewnością dobrym rozwiązaniem byłoby powołanie zespołu badawczego, w którego skład wchodziliby specjaliści reprezentujący różne dziedziny wiedzy, głównie: pedagodzy, pracownicy socjalni, kuratorzy, psycholodzy, lokalni politycy, osoby reprezentujące organizacje pozarządowe, kościoły, policję i inni. Obecność interdyscyplinarnego zespołu pozwoliłaby na szczegółowe rozpoznanie określonej przestrzeni społecznej z uwzględnieniem następujących warstw:

- struktury społeczno-socjalnej (pozycja socjalna/środowisko, podział władzy, posiadania - w tej warstwie m.in. wyodrębnione zostałyby obszary nierówności, enklawy biedy w środowisku, nierówności, segregacji, zajmowania funkcji związanych z władzą i funkcji kluczowych oraz wyposażenie infrastruktury);

- struktury wewnętrznej (stosunki wymiany i kooperacji organizacji i administracji państwa socjalnego);

- sieci (w sensie istniejących i możliwych do wytworzenia kontaktów);

- jednostki (rodzina, przypadki, uczestnicy, wolontariusze, gospodarstwa domowe).

\section{Implikacje praktyczne pracy z byłymi więźniami sprzyjające inkluzji społecznej}

Rozumienie przestrzeni społecznej z perspektywy relacyjnej wyznacza określone działania szczególnie dla praktyki socjalnej i pedagogów. W projektowaniu tegoż działania problemy rodziny należy rozpatrywać właśnie z perspektywy danej przestrzeni społecznej z uwzględnieniem wzajemnych interaktywnych relacji zachodzących pomiędzy wszystkimi mieszkańcami a ich środowiskiem społeczno-ekologicznym.

Ewa Marynowicz-Hetka zauważa, że „Znaczenie analizy środowiska życia jednostki jest niezwykle istotne przy projektowaniu (współprojektowaniu razem z podmiotami współuczestniczącymi w działaniu) i procesie diagnostycznym optymalizacji środowiska w celu jego przekształcenia. W tym procesie nie można pominąć nie tylko oczywistych elementów oceny sytuacji jednostki, grupy lub społeczności, lecz również, i co najważniejsze z punktu widzenia dobrego zrozumienia 
istoty wzajemnych zależności między jednostką i środowiskiem, także oceny zasobów środowiska, warunkujących możliwości probabilistycznych ocen i diagnoz cząstkowych" (Marynowicz-Hetka 2009, s. 59). Z pewnością są to cenne uwagi $\mathrm{w}$ kontekście projektowania pracy $\mathrm{z}$ byłymi skazanymi. Taka diagnoza środowiska życia pozwala na ustalenie zarówno negatywnych, jak i korzystnych sytuacji w środowisku życia określonej osoby. Trzeba zdecydowanie więcej uwagi poświęcić uwarunkowaniom pozytywnym, które mogłyby stanowić podstawę procesu włączania byłego więźnia w środowisko społeczne. Konieczne jest przeanalizowanie więzi jednostki ze środowiskiem, z poszczególnymi osobami z rodzin, sąsiedztwa, a także wskazanie rozwiązań, które pozwoliłyby na ich odbudowanie w przypadku ich całkowitego zerwania. Ważne jest także poznanie stosunku samego skazanego do środowiska. Powołując się na typologię Radlińskiej, która wyróżniła postawę czynną (określaną również jako twórczą), bierną i obronną, zauważa się, że wśród skazanych, wobec których podejmowane są różnorodne formy pomocy, najczęściej dominuje postawa bierna, w dalszej kolejności pojawia się postawa obronna, a najmniejszą grupę charakteryzuje postawa czynna ${ }^{1}$. W odniesieniu do charakteru badanej grupy - byłych więźniów - podzielam opinię Marynowicz-Hetki w kwestii użycia terminu „postawa” czy „stosunek”, na korzyść tego drugiego określenia (Marynowicz-Hetka 2009, s. 62). Należałoby zastanowić się nad przyczynami dominacji biernego stosunku skazanych do środowiska życia. Z pewnością jest on następstwem izolacji więziennej, która spowodowała wycofanie się z życia społecznego. Dlatego też ta grupa osób najczęściej unika jakichkolwiek kontaktów społecznych, wręcz odczuwa zaniepokojenie, lęk zarówno przed spontanicznymi, jak i zorganizowanymi kontaktami z ludźmi. Stosunek bierny do środowiska jest wyjątkowo niepomyślny, gdyż wiąże się z nim uległość i bezrefleksyjne podporządkowanie się jakimkolwiek, głównie przypadkowym, niekorzystnym wpływom środowiska. Równie niekorzystny jest stosunek obronny, objawiający się najczęściej negowaniem wszystkich propozycji i rozwiązań, któremu towarzyszy zachowanie agresywne. Należy podkreślić, że taki stosunek jest związany również z lękiem jednostek przed nieznanymi sytuacjami, a także z brakiem wiary w możliwość zmiany swojego dotychczasowego położenia. Najkorzystniejszy jest stosunek czynny, charakteryzujący się aktywnością, otwartością i twórczym stosunkiem do środowiska, który „pojawia się, ale także kształtuje pod wpływem przełamywania przeszkód i hamulców w urzeczywistnianiu wartości, w ulepszaniu warunków środowiskowych [...] kształtują ją czynniki osobowe (zdrowie, wiek, cechy psychiczne) i czynniki pozaosobowe, czyli społeczne. Te ostatnie związane są z działaniem innych, wzorcami pożądanych zachowań, dobrami kultury" (Radlińska 1961, s. 5). Podstawą sukcesu pomocy skierowanej do byłych więźniów jest ukształtowanie właśnie twórczego stosunku do środowiska życia, a ten z kolei uwarunkowany jest głównie indywidualnym potencjałem każdej jednostki, jego wydobywaniem i wzmacnianiem. $\mathrm{Na}$

1 Wnioski uzyskane w wyniku prowadzonych badań autorki tekstu w 2015 roku. 
gruncie pedagogiki społecznej funkcjonuje pojęcie „sił ludzkich” i bardzo dobrze wpisuje się ono w kontekst rozważań na podjęty temat. Definicję określenia „siły ludzkie" można rozpatrywać $\mathrm{z}$ dwóch perspektyw. Pierwsza, która uwzględnia brak pewnej cechy, waloru, którego istnienie można jednak ujawnić w jakiś sposób bądź uzupełnić, zastąpić innym, siły ludzkie definiuje jako: „właściwość, której brak pewnym jednostkom upośledzonym przez los, warunki społeczne, historię; ten brak można wypełniać przez budzenie sił (mogą bowiem być w stanie utajonym) lub kompensować je, wyrównując «brak przez wprowadzenie walorów i uruchomienie sił, które uzupełniają lub przeinaczają procesy selekcji społecznej lub biologicznej»" (Radlińska 1961, s. 110). Druga perspektywa uwzględnia istnienia danego waloru, który wspiera aktywność jednostki - z tego punktu widzenia siły ludzkie rozumiane są jako: „pewna cecha posiadana przez niektóre jednostki (mocne, działające, sprawne) lub grupy (aktywne, wartościowe, związane jakimś zadaniem lub ideą)" (Radlińska 1961, s. 30).

$\mathrm{W}$ pracy $\mathrm{z}$ byłymi skazanymi ważne jest, aby podejmowano takie rozwiązania, które pozwoliłyby na ujawnienie owych sił. Należy dążyć do tego, aby sami skazani i ich najbliżsi dostrzegali u siebie określony potencjał. Często odnalezienie tych właśnie „sił ludzkich” nie jest łatwym zadaniem. Skazani czy członkowie ich rodzin są często zamknięci, przyjmują postawę roszczeniową, obawiając się ukazania swojego prawdziwego oblicza. Jak wcześniej zauważono, ich stosunek do społeczeństwa ma najczęściej charakter bierny i obronny. Należy więc wziąć pod uwagę fakt, że rozbicie tej „ochronnej powłoki” może okazać się niezwykle trudne. Jednak bez dotarcia do wnętrza danej osoby, poznania i uruchomienia jej zasobów nie będzie efektywna jakakolwiek pomoc. W procesie ujawniania sił istotne jest, aby:

1) posiąść umiejętność poszukiwania potencjalnych sił jednostkowych przez odkrywanie tych cech, umiejętności i zainteresowań u poszczególnych osób, które są ukryte, ale które mogą być dostrzeżone i spożytkowane dla rozwoju indywidualnego, jak również będą wzmocnieniem procesu inkluzji społecznej;

2) zadbać o wzmacnianie i „pielęgnowanie” sił już ujawnionych,

3) stworzyć warunki pozwalające na ich kontynuowanie. Ważne jest projektowanie aktywności umożliwiających doznanie satysfakcji, czyli pozwalających na zaspokojenie potrzeby uznania, szacunku, współdziałania, współuczestnictwa (Butrymowicz 1993, s. 9-10).

Uwagi na temat ujawniania się sił społecznych w pełni nawiązują do współczesnych koncepcji pracy socjalnej, a mianowicie: empowermentu, wsparcia społecznego i edukacji środowiskowej. W kontekście przedstawionych podstaw teorii przestrzeni społecznej można wyodrębnić główne etapy postępowania metodycznego w pracy z osobami mającymi za sobą przeszłość więzienną. Ich propozycja przedstawia się następująco:

1) etap - dobra diagnostyka relacyjnych i interakcyjnych powiązań stanowi główny komponent analizy społeczno-przestrzennej, pozwalającej na zidentyfikowanie wielorakich zróżnicowań zachodzących w danej przestrzeni oraz na 
określenie tych elementów, które umożliwiają aktywizację jednostki, rodziny $\mathrm{i}$ innych grup społecznych na danym terenie (Reutlinger 2009, s. 20), rozpoznanie podatności i zdolności oraz odpowiednie rozwijanie i udzielenie wsparcia;

2) etap - praca na zasobach - eksponowanie osobowych i społeczno-przestrzennych zasobów. W dotychczasowej praktyce resocjalizacyjnej w większości dominowało deficytowe ujęcie. Eksponowano braki, problemy skazanych, ich rodzin i to wokół tego oscylowały wszelkie działania pomocowe. W niewielkim zakresie dostrzegano potencjały. Należy całkowicie odwrócić dotychczasowe proporcje, tzn. trzeba skupić się na poszukiwaniu i eksponowaniu mocnych stron i przy tej okazji eliminować deficyty. Pracując na zasobach, można wykorzystać m.in. praktyczne aspekty metody krótkoterminowej skoncentrowanej na rozwiązaniach problemu;

3) etap - podkreślenie zasadniczego zainteresowania byłych skazanych ich indywidualnym rozwojem i przezwyciężanie wyzwań życiowych w zakresie materialnych i społecznych uwarunkowań środowiskowych poprzez jednoczesne współkształtowanie współżycia w konkretnych przestrzeniach;

4) etap - przejście od analizy przypadku do badania przestrzeni życiowej wraz z jego tery torialnością i uwzględnieniem zapotrzebowania ludności zamieszkującej daną miejscowość;

5) etap - budowanie sieci - powiązań zarówno w zakresie poziomów, jak i ich społecznej przestrzeni z szerszymi obszarami oddziaływania pomocniczego oraz ciągłe zabieganie o ulepszenie kooperacji i koordynacji społeczno-socjalnej oferty i usług;

6) etap - samopomoc i samoorganizacja - odkrywanie i wspieranie kompetencji zawartych w przestrzeni życiowej określonej grupy osób przy odpowiednim wyważaniu proporcji profesjonalnej interwencji z posiadanymi zasobami na danym obszarze społecznym - zadbanie o aktywizację sił i możliwości adresatów, ale też wrażliwość wobec przesadnego wysiłku: „zmęczenia się materiału”;

7) etap - kooperacja i koordynacja - główne zadanie polega na powiązaniu i integracji różnych działań i aktorów z konkretnym przypadkiem i sytuacją przy jednoczesnym zadbaniu o różnorodność działań (współpraca pracowników socjalnych, asystentów rodziny, kuratorów sadowych);

8) etap - ponadgrupowa i ponadresortowa orientacja - unikanie biurokratyzacji przy organizacji pomocy, łączenie prac nie w profilu instytucjonalnych struktur, ale według potrzeby adresatów. Należy zwrócić uwagę na obecne i faktyczne potrzeby skazanych. To one powinny być wyznacznikiem działań wspierających. Osobom podejmującym jakiekolwiek działania pomocowe zbyt często się wydaje, że to ich propozycje są najwłaściwsze. Jak wcześniej zauważono, należy uwierzyć w kompetencje podmiotów będących przedmiotem zainteresowania. Nie ograniczać działań wspierających byłego więźnia wyłącznie do np. dozoru kuratora. Były więzień powinien na równych prawach korzystać z różnorodnych instytucji kultury znajdujących się w danym środowisku lokalnym; 
9) etap - równoważąca i pośrednicząca działalność na rzecz rozwoju kompetencji - tworzenie, podtrzymywanie i rozwijanie ponadsektorowych struktur i projektów w wąskim i średnim zakresie oddziaływania;

10) etap - społeczno-socjalno-polityczne zaangażowanie: rozwijanie wiedzy i praktyki na podstawie dobrze zabezpieczonej interdyscyplinarnej wiedzy na polu społeczno-socjalnej polityki komunalnej (por. Surzykiewicz 2010, s. 215-216).

\section{Podsumowanie}

Wykorzystanie założeń modelu społeczno-przestrzennego w pracy z byłymi skazanymi może okazać się niezwykle cenne i efektywne. Akcentowanie roli środowiska i relacji międzyludzkich w różnego rodzaju działaniach pomocowych jest właściwym spojrzeniem przy wszelkiego rodzaju działaniach pomocowych. Potwierdzenie tej tezy znajdujemy m.in. w charakterystyce nurtu trzeciej socjologii. Piotr Sztompka podkreśla, że „klucz do dobrobytu i szczęścia społeczeństwa leży w pozytywnych relacjach społecznych, w dobrej przestrzeni międzyludzkiej i gęstej przestrzeni moralnej” (Sztompka 2016, s. 336). Sytuacja każdego człowieka w znacznym stopniu uzależniona jest od jakości relacji międzyludzkich zachodzących w określonej przestrzeni społecznej. Projektując i realizując wszelkiego typu działania pomocowe, należy pamiętać, że powodzenie owych działań, poza ustalonymi, charakterystycznymi formami pomocy, uzależnione jest również od „bilansu relacji pozytywnych i negatywnych, a zwłaszcza moralnych i amoralnych” (Sztompka 2016, s. 335), których doświadczają wszyscy ludzie, niezależnie od aktualnej i przeszłej sytuacji życiowej.

\section{Bibliografia}

Pedagogika społeczna Heleny Radlińskiej. W: Badura J., Lepalczyk I. (red.). Człowiek $w$ Pracy $i$ w Osiedlu. „Biuletyn TWWP” 2/92/19, 3/93/19, s. 72-73.

Berger P. L., Luckmann T. (1980). Die gesellschaftliche Konstruktion der Wirklichkeit. Eine Theorie der Wissenssoziologie. Frankfurt am Main.

Deinet U. (2007). Sozialräumliche Konzeptentwicklung und Kooperation im Stadtteil. W: Deinet U., Gilles C., Knopp R. (red.). Neue Perspektiven in der Sozialraumorientierung. Dimensionen-Planungs-Gestaltung, Berlin: Frank \& Timme.

Goffman E. (2011). Instytucje totalne. Sopot: GWP.

Hinte W., Treess (2007). Sozialraumorientierung in der Jugendhilfe. Theoretische Grundlagen. Handlungsprinzipien und Praxisbeispiele einer kooperativ-integrativen Pädagogik. Weinheim-München.

Hopmann A. (2006). Sozialraumorientierung in der Jugendhilfeplanung. W: Deinet U., Gilles C., Knopp R. (Hrsg.), Neue Perspektiven in der Sozialraumorientierung. Dimensionen. Planung. Gestaltung. Berlin. 
Kessl F., Reutlinger C. (2007). Sozialraum. Eine Einführung. Wiesbaden: VS Verlag. Löw M., Steets S., Stoetzer S. (2008). Einführung in die Stadt - und Raumsoziologie. Opladen: Budrich.

Marynowicz-Hetka E. (red.) (1993). Z problematyki profilaktyki alkoholowej wśród dzieci i młodzieży szkolnej. Łódź: Archidiecezjalne Wydawnictwo Łódzkie.

Marynowicz-Hetka E. (2009). Pedagogika społeczna. Podręcznik akademicki, t. 1. Warszawa: PWN.

Piekarski J., Pilch T., Theiss W., Urbaniak-Zając D. (red.). (2010). Edukacja społeczna wobec problemów współczesnego człowieka i społeczeństwa. Łódź: Wydawnictwo Uniwersytetu Łódzkiego.

Radlińska H. (1961). Pedagogika społeczna. Warszawa: Ossolineum.

Robinson S. M. (1960). Juvenile Delinquency. Its Nature Control. New York, s. 87. Reutlinger C. (2009). Sozialraumorientierte Vernetzung in „sozialen Brennpunkten”der territoriale Aspekt im Programm E\&C. W: Kessl F., Otto H.-U. (red.). Soziale Arbeit und Soziales Kapital, Zur Kritik lokaler Gemeinschaftlichkeit. Opladen. Staub-Bernasconi S. (2007). Soziale Arbeit als Handlungswissenschaft. Ein Lehrbuch. Bern: Haupt.

Sztompka P. (2016). Kapitał społeczny. Teorie przestrzeni międzyludzkiej. Kraków: Wydawnictwo ZNAK.

\title{
WORK WITH THE CONVICTED FROM THE PERSPECTIVE OF THE SOCIAL-SPATIAL MODEL
}

\begin{abstract}
Social rehabilitation of former prisoners has been set in the spotlight of both scientists, practitioners and a significant part of the population. The approach that dominates in contemporary theoretical reflection and methodological contexts concerning rehabilitation work is the indeterministic approach, remaining mostly in the mainstream of cognitive and interactionist vision of man and society. Modern activity connected with rehabilitation is inspired by sociology, pedagogy of culture, psychology and pedagogy of creativity, cognitive psychology, personalistic pedagogy, heuristics, phenomenological approaches which derive from that field. This article attempts to use the socio-spatial model in the inclusive rehabilitation process. Practical remarks resulting from the presented reflections were interpreted in relation to former prisoners. This results from the experience of the author of the text, who is leading a research in the group of convicted persons. However, the issues analyzed in the study can be used in the practice of inclusive rehabilitation towards all people needing assistance and support in a particular social space.
\end{abstract}

Keywords: rehabilitation, inclusion, socio-spatial model, relation, social readaptation, convicted. 
Anna H. Fidelus - doktor habilitowany nauk społecznych, profesor nadzwyczajny Uniwersytetu Kardynała Stefana Wyszyńskiego w Warszawie. Wybrane publikacje książkowe: Determinanty readaptacji społecznej skazanych (Warszawa 2012), Od stereotypu do wykluczenia (Warszawa 2014). Adres e-mailowy: a.fidelus@uksw.edu.pl. 